\title{
Between Internal Control System and Information Asymmetry on Accounting Fraud
}

\author{
Ida Ayu Nyoman Yuliastuti ${ }^{1}$, and Daniel Raditya Tandio ${ }^{2}$ \\ \{ida.yuliastuti@unmas.ac.id ${ }^{1}$, daniel.radityatandio@gmail.com ${ }^{2}$ \} \\ Economy Faculty of Mahasaraswati Denpasar University, Bali, Indonesia ${ }^{1,2}$
}

\begin{abstract}
LPD assets developments in Badung Regency is so fast, making these financial institutions susceptible to accounting fraud. Accounting fraud can be influenced by several factors such as the internal control system, information asymmetry and unethical behavior. Based on this, the purpose of this research was to determine the effect of the internal control system on accounting fraud and unethical behavior as a mediating variable and to determine the effect of information asymmetry on accounting fraud and unethical behavior as a mediating variable in LPD Badung. The sample in this study were all LPD in Badung Regency with 122 LPD. The analysis tool used is Partial Least Square (PLS). The results of this study prove that unethical behavior can provide full mediation between internal control system and accounting fraud. Other results also found, unethical behavior gives partial mediation between information asymmetry and accounting fraud.
\end{abstract}

Keywords: fraud, unethical behavior, internal control system, information asymmetry

\section{Introduction}

Culture-based development has made Bali a destination for both foreign and domestic tourists (Putra and Yuliastuti, 2019)[21]. The development of the tourism sector will also influence economic development, including the development of financial institutions such as the Lembaga Perkreditan Desa (LPD). Public trust in LPD is getting higher, people are starting dare to put their funds in LPD, compared to financial institutions overseen by the Otoritas Jasa Keuangan (OJK). LPD is financial institution that is exempted by OJK. LPD in Bali is currently growing rapidly, in 2017 LPD Bali recorded an encouraging performance despite the midst of a slowdown in the island's economic growth. This is proven by the increase in total assets held by LPD in 2017 reaching 18.47 trillion rupiah, up by $22.5 \%$ compared to the value of assets recorded at the end of 2016 at 16.06 trillion rupiah (Bisnis.com, 2018)[6].

According to Suamarnayasa (2018), LPD that have large assets have not been evenly distributed and are still concentrated in Badung, Denpasar and Gianyar. LPD in Badung are noted to have the greatest assets, reaching Rp. 5.9 trillion, compared to the other two regions which are recorded as having large assets as well as Gianyar Rp. 3.6 trillion and Denpasar Rp. 1.9 trillion (LPLPD, 2018)[15]. The LPD assets of Badung are large, because LPD in Badung have LPD administrators and supervisors who are already professional as evidenced by the level of education of their average master degree graduates. Another factor, also because the economic capacity of the people in Badung is better than other regional residents.

LPD assets in Badung is so rapid, making these financial institutions vulnerable to accounting fraud. In general, accounting fraud is related to corruption cases. As reported in the IDN Times (2018), there have been corruption cases up to Rp.15 billion in the LPD Kapal, Mengwi, Badung, which were carried out by the LPD head who had served for 20 years. Initially, the LPD Kapal had healthy finances, but around the end of 2017 there were irregularities in its financial statements, where customers began to unable to withdraw money from the LPD. Financial reports are very important for an institution (Arie et al, 2018)[5]. Like cooperatives, LPDs should also hold meetings with members, so that LPD members can also receive copies of financial statements, to participate in reviewing fiscal information over the past year. This is needed to prevent the desire to commit accounting fraud.

Judging from this case, corruption is one form of accounting fraud. According to Amalia (2015)[3] one of the factors that can influence accounting fraud that occurs is the internal control system. Weak internal controls can provide a person's opportunity to conduct unethical behavior, so that it can 
lead to accounting fraud that can harm an entity (Shintadevi, 2015)[23]. More effective internal control of financial statements can reduce the possibility of unethical behavior that can lead to fraudulent financial reporting (Spatecen, 2012)[24].

Other factors that can also influence accounting fraud are information asymmetry (Amalia, 2015)[3]. Information asymmetry arising from industry and the complexity of a company can increase the likelihood of financial report fraud (Ndofor, 2015)[19]. According to Fitri (2016)[9] information asymmetry is an imbalance that occurs between owners (pricipal) with the manager (agent). If information imbalances occur in a financial institution such as the LPD, it will provide an opportunity for the LPD head to conduct unethical behavior such as misappropriation of funds and data manipulation, so that this can lead to accounting fraud.

One's unethical behavior can also influence the occurrence of accounting fraud, where the more someone behaves unethically, the greater the likelihood of fraud occurring in an agency. According to Shitadevi (2015)[23], unethical behavior occurs because of a lack of supervision carried out, thus providing an opportunity for someone to take unethical actions that can harm the institution itself. Unethical behavior that occurs can also be caused due to dissatisfaction and disappointment with the results obtained with what they have done. Based on these problems and background, the purpose of this study is to determine unethical behavior in mediating the internal control system and information asymmetry on accounting fraud in the LPD in Badung.

\section{Literature Review}

\subsection{Agency Theory}

Agency theory is used to predict and explain the behavior of the parties involved in a company (Arie et all, 2018)[5]. According to Jensen and Meckling (1976)[11], agency theory is a contract that occurs between the manager (agent) and the owner (principal). Agency theory is often used to explain accounting fraud. In this study, Pekraman Village acted as principal, while LPD administrators acted as agents. Problems arising from differences in interests between principals and agents are called agency problems.

\subsection{Attribution Theory}

Attribution theory was developed by Kelley (2007), who views that attribute leadership behavior can explain how leadership behavior occurs. In this study, attribution theory is used to find out how the actions and decisions taken by leaders or authorized people, including unethical actions and fraud occur.

\subsection{Accounting Fraud}

Accounting fraud can occur if there is a behavior or a policy that removes or hides important company information that is actually by manipulating financial data, which can benefit oneself or a certain group of parties (Pamungkas, 2016)[20]. According to Amiruddin (2017)[4] accounting fraud that occurs is an act or policy that is wrong in the form of concealment and disguise in presenting financial statements and assets of management organizations that benefit themselves.

\subsection{Unethical Behavior}

According to Fitri (2016)[9] unethical behavior is a deviant attitude that is carried out by a person to achieve a certain goal, but that goal is different from the goals previously agreed upon. If this unethical behavior is allowed then it can develop into behavior that is very broad and difficult to trace, giving rise to adverse consequences (Ahriati, 2015)[2]. Unethical behavior that someone has will also lead the person to commit accounting fraud.

\subsection{Internal Control System}

According to Government Regulation Number 60 of 2008 concerning the Government's Internal Control System (SPIP) states that the internal control system is an integral process in the actions taken continuously by the leadership and all employees to provide adequate confidence in achieving organizational goals through effective activities and efficient, reliability of financial reporting, safeguarding state assets and compliance with laws and regulations. So, the more effective the internal control system is applied in an entity, the lower the accounting fraud that occurs (Ahriati, 2015)[2]. 


\subsection{Information Asymmetry}

According to Amalia (2015)[3], information asymmetry is a situation where there is an inconsistency in information between parties who have information and those who need information. The existence of this information asymmetry will cause a gap in internal financial knowledge, so that the management can do engineering to increase its own profits. in the public sector, if financial reports published to the public are not in accordance with the actual situation, then this can provide an opportunity to commit fraudulent actions or data manipulation.

\subsection{Hypotheses}

\subsubsection{Effect Of Internal Control System On Accounting Fraud With Unethical Behavior As A Mediation Variable}

The internal control system is a process that is influenced by management to provide adequate confidence as a guideline to improve effectiveness and efficiency, reliability of financial statements and compliance with the law (Randiza, 2016). Weak internal control systems can provide a person's opportunity to conduct unethical behavior, so that it can lead to accounting fraud that can harm an entity (Shintadevi, 2015)[23]. Based on the description, the hypothesis that can be built is:

H1: Unethical behavior can mediate the influence of the internal control system on accounting fraud.

\subsubsection{Effect of Information Asymmetry on Accounting Fraud with Unethical Behavior as Mediator}

According to Fitri (2016)[9], information asymmetry is an information imbalance that is held between the principal and the agent. In the public sector such as the LPD, if there is an imbalance of information between leaders or public employees, then this can provide an opportunity for leaders or employees to conduct unethical behavior. Unethical behavior itself is a deviant attitude that is carried out by someone to achieve a certain goal but that goal can cause harm to the other party (Fitri, 2016)[9]. If the unethical behavior that is owned by someone is not controlled, it can lead to behaviors such as misappropriation of funds and data manipulation that will lead to accounting fraud. Based on the description, the hypothesis that can be built is:

$\mathrm{H} 2$ : $\quad$ Unethical behavior can mediate the effect of information asymmetry on accounting fraud.

\section{Research Methods}

The type of data used in this study is primary data, where the data collection technique is using a questionnaire, which lists the statements that must be answered by the respondent. This questionnaire uses assessments with skalia likert 1-5 with details strongly disagree (sts) given a score of 1, disagree (ts) given a score of 2 , neutral (n) given a score of 3, agree (s) given a score of 4, and strongly agree (ss) were given a score of 5 . The variables used in this study were accounting fraud as the dependent variable, internal control system and information asymmetry as independent variables, and unethical behavior as mediating variables.

\subsection{Operational Definition of Variables \\ 3.1.1 Internal Control System}

The internal control system is an integral process in activities carried out continuously by the leadership and all employees to provide adequate confidence in achieving organizational goals through effective and efficient activities, reliability of financial statements, safeguarding state assets and compliance with laws and regulations (Fitri, 2016)[9]. The statement instrument used was measured by a Likert scale 1-5, and used five indicators developed into five statement items by Fitri (2016)[9]. The five indicators of internal control system variable statements are: 1) Control environment, 2) Risk assessment, 3) Control activities, 4) Monitoring, and 5) Information and communication. 


\subsubsection{Information Asymmetry}

Information asymmetry is a condition where there is information misalignment between the owner (principal) and the manager (agent) (Amalia, 2015). The statement instruments used were measured using the Likert scale 1-5, and used one indicator developed into two statement items by Amalia (2015)[3]. The indicators of the information asymmetry variable statement, namely the management of funds knows more about an agency's information than the owner of the fund.

\subsubsection{Unethical Behavior}

Unethical behavior is a deviant attitude by a person to achieve a certain goal, which is different from the goals previously agreed upon (Fitri, 2016)[9]. The statement instruments used were measured using the Likert scale 1-5, and used four indicators developed into four statement items by Fitri (2016)[9]. The indicators of statement of unethical behavior variables are 1) Management behavior that misuses position, 2) Management behavior that misuses organizational resources, 3) Management behavior that misuses power, and 4) Behavior that does nothing.

\subsubsection{Accounting Fraud}

According to Karyono (2013)[12] accounting fraud is an illegal act and intentional deviation for certain purposes such as deceiving other parties by making misstatements in financial statements carried out by people, both from within and from outside the organization. The instrument used was measured by a Likert scale 1-5, and used three indicators developed into six item statements by Karyono (2013)[12]. The three indicators of accounting fraud variable statements are: 1) The tendency to misuse assets, 2) The tendency to make material misstatements of financial statements, and 3) Corruption.

\subsubsection{Population and Sample}

The population in this study were all LPD in Badung Regency, totaling 122 LPDs. The sampling technique used is saturated sampling (census), where all members of the population are sampled. So the sample in this study was 122 LPDs in Badung.

\subsubsection{Analysis Technique}

The data analysis used in this study is the Partial Least Square (PLS) approach in this case using SmartPLS 2.0 software. The data analysis method used is the inner model (test the validity and reliability of data) and the outer model (structural model). The analytical methods carried out include descriptive statistics and inferential statistics (outer model test, inner model test).

\section{Results and Discussion}

The questionnaire was distributed by 122 questionnaires to each LPD in Badung Regency. Of the 122 questionnaires that returned only 110 questionnaires, which did not return as many as 12 questionnaires and there were 4 questionnaires that did not meet the requirements because they were not filled in completely, so the questionnaires that could be processed in this study were 106 questionnaires.

\subsection{Outer Model (Test Validity and Data Reliability) \\ 4.1.1 Convergent Validity Test}

This test is conducted to determine the validity of the indicators used, and indicators are declared valid if weights or loadings factors range above 0.50 . The results of the convergent validity evaluation in Figure 1 below show that there are several reflective indicators that produce a loading factor value of $<0.5$, which means that some of the construct indicators are invalid, for more details the factor loading values of all indicators can be seen in Table 1 below. 


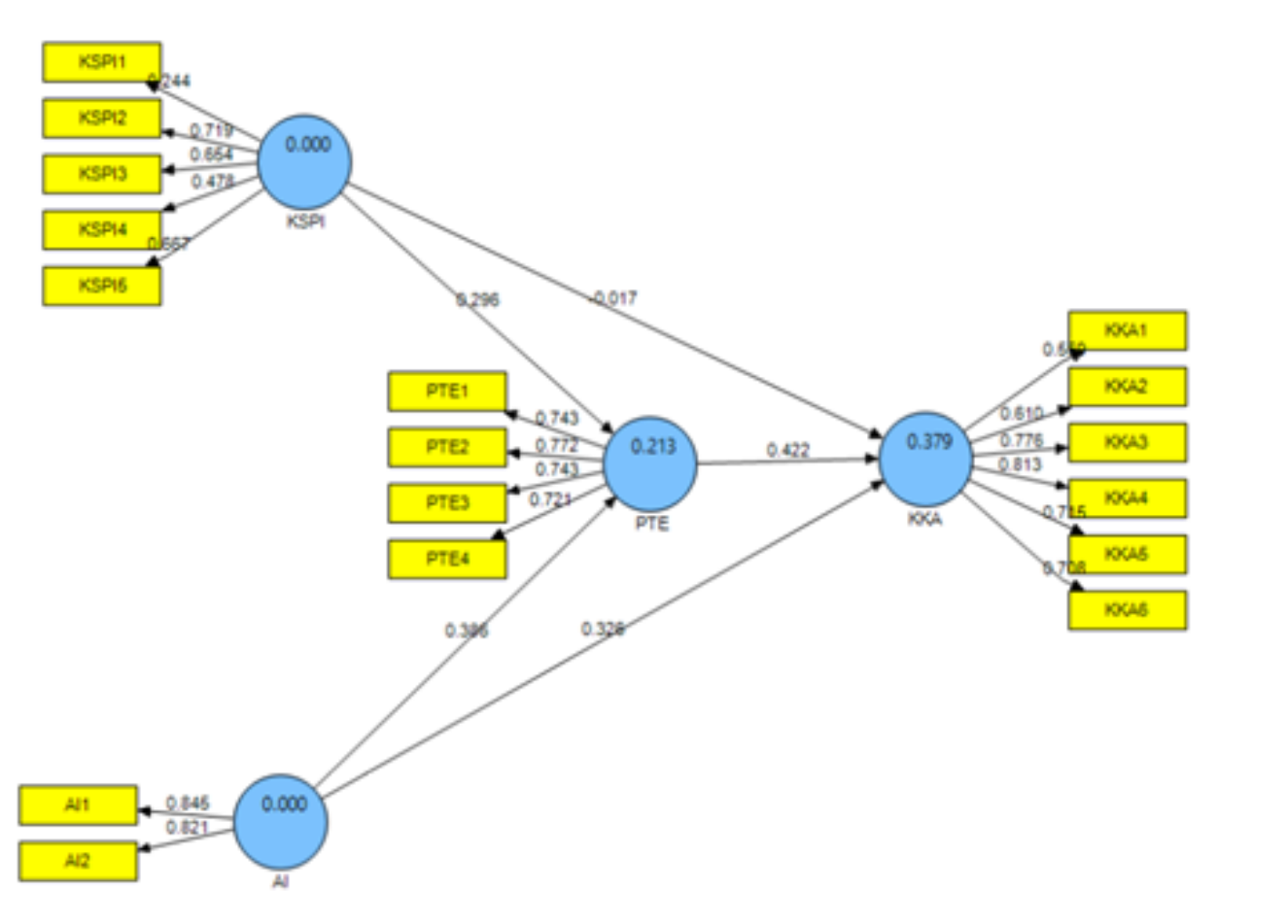

Figure 1. Value of loading factor

Table 1. Uji covergent validity

\begin{tabular}{|c|c|c|c|c|}
\hline No. & Variabel & Indikator & Weights or Loadings & Keterangan \\
\hline \multirow{5}{*}{1.} & \multirow{5}{*}{$\begin{array}{l}\text { Keefektifan Sistem } \\
\text { Pengendalian Internal } \\
\text { (KSPI) }\end{array}$} & KSPI 1 & 0.244096 & Tidak Valid \\
\hline & & KSPI 2 & 0.719308 & Valid \\
\hline & & KSPI 3 & 0.654369 & Valid \\
\hline & & KSPI 4 & 0.477882 & Tidak Valid \\
\hline & & KSPI 5 & 0.667368 & Valid \\
\hline \multirow{2}{*}{2.} & \multirow{2}{*}{ Asimetri Informasi (AI) } & AI 1 & 0.845264 & Valid \\
\hline & & AI 2 & 0.820572 & Valid \\
\hline \multirow{4}{*}{3.} & \multirow{4}{*}{$\begin{array}{l}\text { Perilaku Tidak Etis } \\
\text { (PTE) }\end{array}$} & PTE 1 & 0.742988 & Valid \\
\hline & & PTE 2 & 0.771675 & Valid \\
\hline & & PTE 3 & 0.742860 & Valid \\
\hline & & PTE 4 & 0.721074 & Valid \\
\hline \multirow{6}{*}{4.} & \multirow{6}{*}{$\begin{array}{l}\text { Kecenderungan } \\
\text { Kecurangan Akuntansi } \\
\text { (KKA) }\end{array}$} & KKA1 & 0.550022 & Valid \\
\hline & & KKA2 & 0.610119 & Valid \\
\hline & & KKA3 & 0.775778 & Valid \\
\hline & & KKA4 & 0.812782 & Valid \\
\hline & & KKA5 & 0.714658 & Valid \\
\hline & & KKA6 & 0.708235 & Valid \\
\hline
\end{tabular}

Source: Result Data Processing, 2019

In table 1 above, it can be seen that the KSPI 1 and KSPI 4 indicators are invalid because they have a value of loading factor $<0.5$, so that this indicator is omitted.

\subsubsection{Discriminant Validity Test}

This test is conducted to determine the correlation between each indicator with all existing latent variables, which are valid if the cross loading correlation value of all indicators used to form latent variables is greater than the correlation with other latent variables. In table 2 , it can be seen that all 
indicators are declared valid because they have cross loading correlation values for all indicators of information asymmetry (AI), accounting fraud (KKA), internal control system (KSPI) and greater latent behavior (PTE) other cross-variable variable cross loading correlation values.

Table 2. Uji discriminant validity

\begin{tabular}{|c|c|c|c|c|}
\hline & AI & KKA & KSPI & PTE \\
\hline AI1 & 0.844711 & 0.436499 & -0.143699 & 0.270570 \\
\hline AI2 & 0.821164 & 0.356618 & 0.016281 & 0.324495 \\
\hline KKA1 & 0.144790 & 0.549894 & -0.028410 & 0.360194 \\
\hline KKA2 & 0.283278 & 0.609572 & 0.181856 & 0.373660 \\
\hline KKA3 & 0.384687 & 0.775918 & 0.131462 & 0.469851 \\
\hline KKA4 & 0.441540 & 0.812667 & 0.102510 & 0.409597 \\
\hline KKA5 & 0.321104 & 0.715214 & -0.105539 & 0.359575 \\
\hline KKA6 & 0.379217 & 0.708270 & -0.075122 & 0.238979 \\
\hline KSPI2 & 0.038435 & 0.112648 & 0.730184 & 0.196248 \\
\hline KSPI3 & -0.129908 & -0.006068 & 0.642379 & 0.155991 \\
\hline KSPI5 & -0.106409 & 0.002856 & 0.713345 & 0.187796 \\
\hline PTE1 & 0.325473 & 0.385461 & 0.195139 & 0.748807 \\
\hline PTE2 & 0.263306 & 0.355001 & 0.290062 & 0.773862 \\
\hline PTE3 & 0.182824 & 0.417951 & 0.185345 & 0.740181 \\
\hline PTE4 & 0.281378 & 0.429931 & 0.102755 & 0.715416 \\
\hline
\end{tabular}

Source: Result Data Processing, 2019

\subsubsection{Average Variance Extracted (AVE)}

This test is done to find out the value that shows the magnitude of the indicator variant contained by the variable. Variables are declared valid if the AVE value ranges above 0.5. Table 3 below shows that AVE $>0.50$, so that all variables are declared reliable.

Table 3. Average variance extracted

\begin{tabular}{|c|l|c|c|}
\hline No. & \multicolumn{1}{|c|}{ Variabel Laten } & AVE & Keterangan \\
\hline 1 & Asimetri Informasi (AI) & 0.693923 & Reliabel \\
\hline 2 & Kecurangan akuntansi (KKA) & 0.591603 & Reliabel \\
\hline 3 & Sistem pengendalian internal (KSPI) & 0.584894 & Reliabel \\
\hline 4 & Perilaku Tidak Etis (PTE) & 0.554815 & Reliabel \\
\hline
\end{tabular}

Source: Result Data Processing, 2019

\subsubsection{Composite Reliability}

This test is conducted to show whether all variables used are reliable, by looking at the composite reliability value and the cronbachs alpha value of more than 0.70 (Ghozali \& Latan, 2015)[10]. Table 4 below shows that the composite reliability value and cronbachs alpha are all variables above 0.70 which means that all variables in this study have good reliability.

Table 4. Composite reliability

\begin{tabular}{|c|l|c|c|c|}
\hline No. & \multicolumn{1}{|c|}{ Variabel Laten } & $\begin{array}{c}\text { Composite } \\
\text { Reliability }\end{array}$ & $\begin{array}{c}\text { Cronbachs } \\
\text { Alpha }\end{array}$ & Keterangan \\
\hline 1 & Asimetri Informasi (AI) & 0.819279 & 0.755928 & Reliabel \\
\hline 2 & $\begin{array}{l}\text { Kecurangan akuntansi } \\
\text { (KKA) }\end{array}$ & 0.850852 & 0.788618 & Reliabel \\
\hline 3 & $\begin{array}{l}\text { Sistem pengendalian } \\
\text { internal (KSPI) }\end{array}$ & 0.737919 & 0.747844 & Reliabel \\
\hline 4 & Perilaku Tidak Etis (PTE) & 0.832807 & 0.732320 & Reliabel \\
\hline
\end{tabular}




\subsubsection{R Square Determination Coefficient}

$\mathrm{R}$ square is used to see the significance value of latent variables. In table 5 below, it can be seen that the R2 value of the Endogenous Latent Variables is 0.378635 and 0.210635 which indicates that the model is good.

Table 5. R2 Variabel Latent Endogen

\begin{tabular}{|c|l|c|}
\hline No. & \multicolumn{1}{|c|}{ Variabel Laten } & R Square \\
\hline 1 & Asimetri Informasi (AI) & 0.378635 \\
\hline 2 & Kecurangan akuntansi (KKA) & \\
\hline 3 & Sistem pengendalian internal (KSPI) & 0.210635 \\
\hline 4 & Perilaku Tidak Etis (PTE) & \\
\hline
\end{tabular}

Source: Result Data Processing, 2019

\subsubsection{Hypothesis Testing}

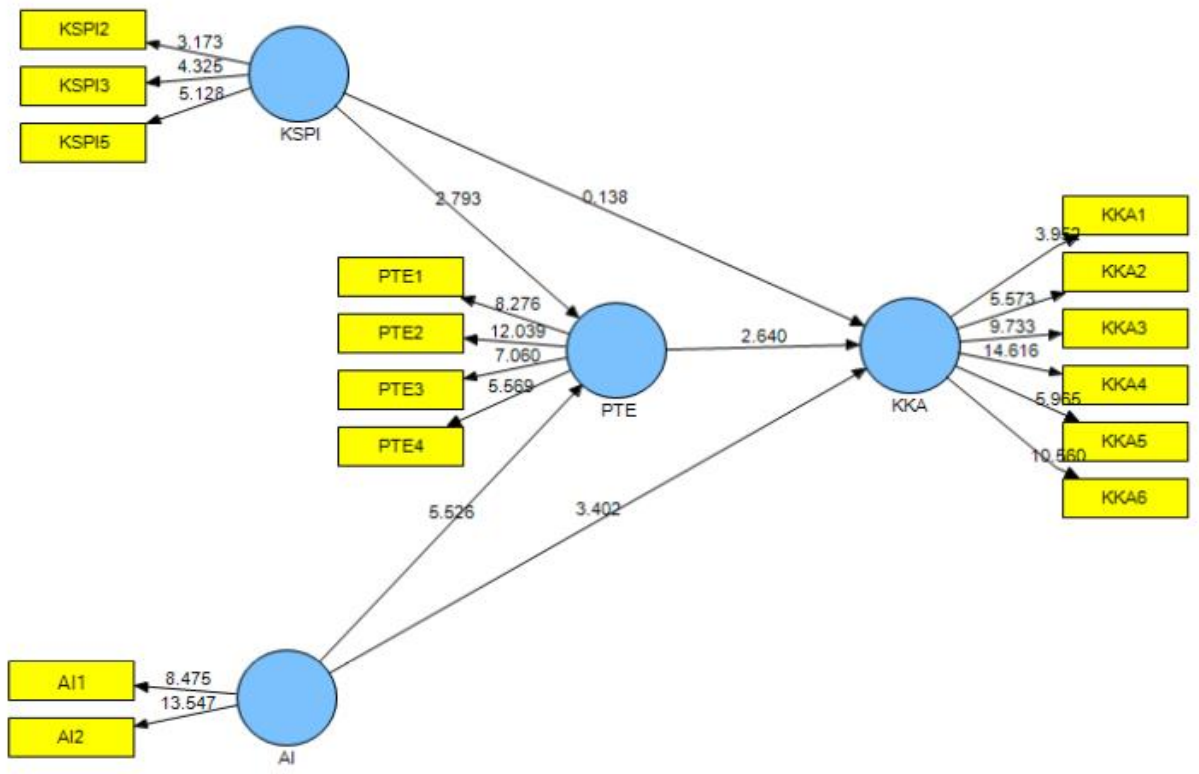

Figure 2. Output bootstrapping

The results for inner weights table is the result of running bootstrapping which is used to determine the direct effect between variables of each hypothesis, which is stated to have an effect if the t-stat value is above 1.96 (5\% significance).

Table 6. Path coeficient

\begin{tabular}{|c|c|c|c|c|c|c|c|}
\hline No & Keterangan & $\begin{array}{c}\text { Original } \\
\text { Sample } \\
(\mathbf{O})\end{array}$ & $\begin{array}{c}\text { Sample } \\
\text { Mean (M) }\end{array}$ & $\begin{array}{c}\text { Standard } \\
\text { Deviation } \\
(\text { STDEV) }\end{array}$ & $\begin{array}{c}\text { Standard } \\
\text { Error } \\
\text { (STERR) }\end{array}$ & T-Stat & Signifikansi \\
\hline & $\begin{array}{c}\text { Asimetri } \\
\text { Informasi -> } \\
\text { Kecurangan } \\
\text { akuntansi }\end{array}$ & 0.325461 & 0.328192 & 0.095655 & 0.095655 & 3.4024 & Signifikan \\
\hline $\begin{array}{c}\text { Asimetri } \\
\text { Informasi -> } \\
\text { Perilaku } \\
\text { Tidak Etis }\end{array}$ & 0.379118 & 0.382262 & 0.068611 & 0.068611 & 5.5256 & Signifikan \\
\hline $\begin{array}{c}\text { Sistem } \\
\text { pengendalian } \\
\text { internal -> }\end{array}$ & 0.021630 & -0.047878 & 0.157238 & 0.157238 & 0.1375 & Tidak \\
\hline
\end{tabular}




\begin{tabular}{|c|c|c|c|c|c|c|c|}
\hline & $\begin{array}{c}\text { Kecurangan } \\
\text { akuntansi }\end{array}$ & & & & & & \\
\hline 4 & $\begin{array}{c}\text { Sistem } \\
\text { pengendalian } \\
\text { internal -> } \\
\text { Perilaku } \\
\text { Tidak Etis }\end{array}$ & 0.290563 & 0.289116 & 0.104028 & 0.104028 & 2.7931 & Signifikan \\
\hline 5 & $\begin{array}{c}\text { Perilaku } \\
\text { Tidak Etis -> } \\
\text { Kecurangan } \\
\text { akuntansi }\end{array}$ & 0.422001 & 0.390736 & 0.159848 & 0.159848 & 2.6400 & Signifikan \\
\hline
\end{tabular}

Source: Result Data Processing, 2019

Based on table 6 above it can be explained that:

1. Information asymmetry towards accounting fraud results in a coefficient of 0.325461 and $t$-statistics of $3.402463>1.96$, so that it can be stated that information asymmetry has a positive effect on accounting fraud.

2. Information Asymmetry towards unethical behavior produces a coefficient of 0.379118 and $\mathrm{t}$ statistics of 5.525643>1.96, so that it can be stated that information asymmetry has a positive effect on unethical behavior.

3. The internal control system of accounting fraud results in a coefficient of -0.021630 with a t-statistic value of $0.137565<1.96$, so that it can be stated that the internal control system has no effect on accounting fraud.

4. The internal control system for unethical behavior produces a coefficient of 0.290563 with a tstatistic value of 2.793111> 1.96, so that it can be stated that the internal control system has a positive effect on unethical behavior.

5. Unethical behavior towards accounting fraud results in a coefficient of 0.422001 with a t-statistic value of 2.640010>1.96, so that it can be stated that unethical behavior has a positive effect on accounting fraud.

\subsection{Discussion of Research Results}

4.2.1 Effect of The Internal Control System on Accounting Fraud With Unethical Behavior as A Mediating Variable

Based on the results of the path coefficient test shows that the internal control system has no effect on accounting fraud, while the internal control system has an effect on unethical behavior and unethical behavior also affects accounting fraud. This means that unethical behavior can provide full mediation in the relationship of the internal control system to accounting fraud. The first hypothesis which states unethical behavior can mediate the effect of the internal control system on proven accounting fraud, so $\mathrm{H} 1$ is accepted.

This means that the weak internal control system in the LPD in Badung Regency will not directly affect one's desire to commit accounting fraud. However, if the LPD's internal control system is weak, it will be able to provide someone the opportunity to conduct unethical behavior, so that it will lead to the desire to commit accounting fraud, such as corruption that occurred in the Ship LPD, Mengwi, Badung conducted by the LPD Head and has cost the LPD customers up to Rp.15 billion.

\subsubsection{Effect of Information Asymmetry on Accounting Fraud with Unethical Behavior as Mediator}

From Table 6 above it can be seen that information asymmetry has a significant effect on accounting fraud. In addition, information asymmetry also has a significant effect on unethical behavior and unethical behavior also has a significant effect on accounting fraud. This proves that unethical behavior gives the effect of partial mediation in the relationship of information asymmetry to accounting fraud, so the second hypothesis which states unethical behavior can mediate the effect of information asymmetry on proven accounting fraud. 


\section{Conclusions, Limitation and Suggestion}

\subsection{Conclusion}

Based on the results of the analysis and discussion, conclusions can be drawn as follows:

1. Unethical behavior can provide the full mediation effect in the relationship of the internal control system to accounting fraud, so the first hypothesis which states unethical behavior can mediate the effect of the internal control system on accepted accounting fraud.

2. Unethical behavior gives the effect of partial mediation in the relationship of information asymmetry to accounting fraud, so the second hypothesis that states unethical behavior can mediate the effect of information asymmetry on accounting fraud is accepted.

\subsection{Limitation}

Current research still has many disadvantages and limitations, including the following:

1. There are still answers to questionnaires that are not filled in completely and inconsistently. Respondents tended to be less careful about existing questionnaire statements, so many statements were not answered or had inconsistent answers. This can be anticipated by assisting and supervising the respondent in answering the statements on the questionnaire.

2. Variables that influence accounting fraud used in this study are still limited to three variables, namely the internal control system, information asymmetry and unethical behavior, while there are still other factors that can be used for research that also affect accounting fraud.

\subsection{Suggestion}

The suggestions that researchers can provide are as follows:

1. The internal control system of the LPD must be improved, each employee and boss must comply with applicable regulations so that accounting fraud can be prevented.

2. The financial statements that are usually presented in LPDs should be complemented with performance that contains a summary of the activities carried out and the results achieved in each program by adhering to the applicable accounting rules. With the openness of customers or other parties who have an interest in the LPD, it is expected to prevent accounting fraud that might occur.

3. At the LPD strict sanctions should be applied if the employee behaves unethically, which is not in accordance with the applicable rules.

\section{References}

[1] Adelin, Vani, 2013. The effect of internal control, compliance with accounting rules and unethical behavior towards accounting fraud tendencies. Skripsi: Universitas Negeri Padang

[2] Ahriati, D., Basuki, P dan Widiastuty, E. (2015). Analysis of the influence of the internal control system, information asymmetry, unethical behavior and suitability of compensation for accounting fraud tendencies in the East Lombok District Government. Jurnal InFestasi. Vol. 11, No.1, Juny 2015 Hal. 41 -55 .

[3] Amalia, R. D. (2015). Effect of internal suppression effectiveness, suitability of compensation, apparatus morality and information asymmetry on accounting fraud (empirical study on the Local Government of Siak Sri Indrapura Regency). JOM FEKON Vol. 2 No. October 2, 2015.

[4] Amiruddin. (2017). The performance of government auditors in perspectives ethical behavior and tendency of accounting fraud. IOSR Journal of Economics and Finance (IOSR-JEF). Volume 8, Issue 4 Ver. IV (Jul. -Aug .2017), PP 35-42. e-ISSN: 2321-5933, p-ISSN: 2321-5925.

[5] Arie, Anak Agung Putu Gede Bagus, Ida Ayu Nyoman Yuliastuti, and Gde Bagus Brahma Putra. "The Effect of Cooperative's Characteristic on Financial Reporting Timeliness." Sriwijaya International Journal Of Dynamic Economics And Business 2.4 (2018): 269-292.

[6] Bisnis.com. 2018. Lembaga Perkreditan Desa: LPD Assets Grow Joyfully. Denpasar: Bisnis.com

[7] Drew, J. M Drew, M.E. 2010,"Establishing additionality: fraud vulnerabilities in the clean development mechanism", Accoun ting Research Journal 23(3): 243- 253

[8] Fauwzi, Mohammad Glifandi Hari, 2011. Analysis of the Effectiveness of Internal Control Effectiveness, Perception of Compensation Conformity, Management Morality on Unethical Behavior and Accounting Fraud Trends. Jurnal Akuntansi Universitas Diponegoro

[9] Fitri, Y. (2016). The effect of the effectiveness of the internal control system, accounting 
compliance, information assimilation and individual morality on the tendency of accounting fraud with unethical behavior as an intervening variable (empirical study in the Riau Provincial Government Work Unit). Jom Fekon. Vol. 3 No. 1 (February) 2016.

[10] Ghozali, Imam, 2011. Structural Equation Modeling Metode Alternatif Dengan Partial Least Square (PLS), Edisi 3, Badan Penerbit Universitas Diponegoro: Semarang

[11] Jensen, M. C. and W. H. Meckling. 1976. Theory of the Firm: Managerial Behavior, Agency Cost, and Ownership Structure, University of Rochester, Rochester

[12] Karyono. (2013). Forensic fraud. Yogyakarta: CV Andi Offset

[13] Kyalo, Shadrack Maweu, Aquilars M. Kalio, and Solomon Ngahu. "Role of Fraud Prevention in Enhancing Effective Financial Reporting in County Governments in Kenya: Case of Nakuru County, Kenya."

[14] Lou, Yung-I., and Ming-Long Wang. "Fraud risk factor of the fraud triangle assessing the likelihood of fraudulent financial reporting." Journal of Business \& Economics Research (JBER) 7.2 (2011).

[15] LPLPD. 2019. Total of LPD in Badung. Badung: LPLPD

[16] Mulyani, Pujianik dan Rindah F. Suryawati. 2011. Analysis of the Role and Function of the Government's Internal Control System (SPIP / PP No.60 of 2008) in Minimizing the Level of Misstatement of Local Government Financial Accounting Records. Madura: Universitas Trunojoyo.

[17] Musa, N., Othman, R. M., Ibrahim, D. H. A., \& Din, I. (2012). E-Government Services: The Formal, Technical and Informal components of E-Fraud Prevention for Government Agency. EGovernment, 2(2).

[18] Najahningrum, Anik Fatun. Factors Affecting Fraud: Perception of DIY Provincial Service Officers. Accounting Analysis Journal2.3 (2013).

[19] Ndofor, H. A., Wesley, C and Priem, R. L.(2015). Providing ceos with opportunities to cheat: the effects of complexity-based information asymmetries on financial reporting fraud. Journal of Management, 41(6) 1774-1797.

[20] Pamungkas, I. D. (2016). Effect of ethical orientation and professional commitment to accounting fraud through rationalization as a moderating variable. Jurnal Ekonomi dan Bisnis. Volume 18 Number 01 March 2016. ISSN: 1693-0908.

[21] Putra, Gde Bagus Brahma, and Ida Ayu Nyoman Yuliastuti. "Ability to Produce the Benefits of Medium Small Micro Businesses in Denpasar City and Its Affecting Factors." Jurnal Riset Akuntansi (JUARA) 9.1 (2019): 37-47.

[22] Putri, P. A. A dan Irwandi, S. A (2016). The determinants of accounting fraud tendency. The Indonesian Accounting Review. Vol. 6, No. 1, January - July 2016, pages 99 - 108.

[23] Shintadevi, P. F. (2015). Effect of the effectiveness of internal control, compliance with accounting rules and suitability of compensation for accounting fraud with unethical behavior as intervening variables. Jurnal Nominal. Volume IV Number 2 Tahun 2015.

[24] Spatacean, I. O. (2012). Addressing fraud risk by testing the effectiveness of internalcontrol over financial reporting case of Romanian financial investment companies. Procedia Economics and Finance 3 ( 2012 ) $230-235$.

[25] Thoyibatun, Siti. 2012. Influential Factors Against Unethical Behavior and the Tendency of Accounting Fraud and Its Effects on Organizational Performance. Jurnal Ekonomi dan Keuangan. Vol. 16 , No.2

[26] Times, IDN. 2018. Gelapkan Dana Nasabah Rp. 15 Miliar, Kepala LPD di Mengwi Ditangkap. Bali: IDN Times Bali

[27] Tuanakotta, T. M. 2014. Forensic Accounting and Investigative Audit. Jakarta: Lembaga Penerbit Fakultas Ekonomi Universitas Indonesia (LPFE UI)

[28] Zulkarnain, Rifqi Mirza. 2013. Factors Affecting the Occurrence of Fraud in the Government Sector (Case Study in Surakarta City Offices). Skripsi : Fakultas Ekonomi : Universitas Negeri Semarang. 